\title{
Mother's Knowledge of Continuing Immunization in the Jagir Public Health Center Working Area
}

\author{
Sofina Setiawati ${ }^{1}$, Lutfi Agus Salim ${ }^{2}$ \\ ${ }^{1}$ Undergraduate Student in Department Biostatistics and Demography, Faculty of Public Health, Universitas \\ Airlangga, Surabaya, Indonesia, ${ }^{2}$ Associate Professor in Department Biostatistics and Demography, Faculty of \\ Public Health, Universitas Airlangga, Surabaya, Indonesia
}

\begin{abstract}
Immunization is a priority program in Indonesia that is implemented from the central government to the regions. Immunization is an effort to reduce morbidity, disability and death from diseases that can be prevented by immunization. The child's basic needs including natural immunizations must also be fulfilled by parents. The purpose of this research is to measure mother's knowledge of continuing immunization in the Jagir Public Health Center working area using descriptive research method. The number of samples is 200 people with random sampling technique. Data collection was carried out through interviews using questionnaires and observations. The results of the study that the majority of respondents in 3 villages working area of Jagir Public Health Center know the existence of Jagir Health Center immunization services is very good with an average percentage of $96.5 \%$.
\end{abstract}

Keywords: Immunization children, mother's knowledge.

\section{Introduction}

The WHO began to set the immunization program as a global effort with the Expended Program on Immunization in 1974, which was resolved by the World Health Assembly (WHA). Efforts to achieve this goal various programs based on Primary Health Care have been implemented to improve health status. Coverage of child immunizations in WHO countries still reaches $85 \%$ of babies worldwide have been immunized and there are $19.9 \%$ of infants and children have not been fully vaccinated and remain at risk of disease. Several indicators used by WHO to measure the success of these programs include infant mortality (IMR), underfive mortality rate, maternal mortality (MMR) and life expectancy. One indicator of the MDGs is to reduce child mortality by targeting to reduce the mortality rate of children under five years old (toddlers) by twothirds in the number from 1990 to 2015 meaning that it decreased from 97 per 1000 live births to 32 per 1000 live births. Followed with health indicators in the 2015 Sustainable Development Goals (SDGs) which is the third goal, namely health insurance and health promotion for all ages.
WHO estimates that TB cases in Indonesia are the third largest in the world after China and India, assuming the prevalence of acid-fast bacillus (+) 130 per 100,000 population Since 1991, pertussis cases have emerged as frequently reported cases in Indonesia, around $40 \%$ of pertussis cases attack toddlers. the incidence of tetanus in Indonesia for urban areas is around 67 per 1000 live births, while in rural areas the figure is about 23 times higher at 1123 per 1000 live births with approximately 60,000 infant deaths each year. Furthermore, Hepatitis B is estimated to cause at least one million deaths per year. As for the case of polio, the latest data reported in total there are 295 cases of polio scattered in 10 Provinces and 22 districts/cities in Indonesia. Likewise, with the case of measles, the number of events recorded 30,000 cases reported annually. Cases of diseases that can be prevented by immunization that are of great concern lately are reported that several regions in Indonesia have been declared to have occurred in the Extraordinary Events diphtheria. The mortality rate due to diphtheria in Indonesia is around $15 \%$ and continues to increase. The results of the 2007 Indonesian Health Demographic and Survey (IDHS) showed that infant mortality in Indonesia was 34 per 1000 live births. This figure is lower than the 
infant mortality rate in 2002 to 2003 which reached 35 per 1000 live births ${ }^{(1)}$. Thus, immunization is an effective effort to emphasize infant mortality ${ }^{(2)}$. The Indonesian Ministry of Health has compiled a program as an effort to suppress diseases that can be prevented by immunizing children, such as the Immunization Development Program for children since 1956. The success of infants in getting five basic types of immunization (HB0, BCG, DPT-HB, Polio and Measles) is measured through a complete basic immunization indicator. Basic Health Research Data notes, in 2007 the coverage of complete basic immunization in Indonesia averaged $41.6 \%$. Then it increased in 2010 with an average coverage of $53.8 \%$. In 2013 the average coverage of complete basic immunization increased again, namely 59.2\%.

Immunization comes from the word "immune" which means immune or resistant. Immunization is the provision of immunity against a disease by entering something into the body so that the body is resistant to diseases that are endemic or dangerous to someone ${ }^{(3)}$. Immunization is an attempt to actively raise/increase a person's immunity against a particular disease, so that if one day exposed to the disease will not be sick or only experience minor illness. Some infectious diseases that can be prevented with immunization include: tuberculosis, diphtheria, tetanus, hepatitis B, pertussis, measles, rubella, polio, inflammation of the lining of the brain and inflammation of the lungs. Children who have been immunized will be protected from various dangerous diseases, which can cause disability and death

There are several things that affect the achievement of immunization coverage targets, including false rumors about immunization, the community believes that immunization causes children to become sick, disabled or even die, community understanding, especially parents who are still lacking about immunization and parents' motivation to provide immunizations in children is still low. Anti-immunization Black Campaign is currently 'intense' in several regions in Indonesia, both through seminars and anti-immunization talkshows. Aside from general activities, they also carry out movements through social media such as Twitter, Facebook, mailing lists, or blogs. Halal-haram vaccines, conspiracies and vaccine side effects that can cause disability, autism, or even death are the main issues raised by the antiimmunization group.
The role of a mother in the immunization program is very important, so an understanding of immunization is needed. Likewise with knowledge, beliefs and health behaviors of parents. Lack of socialization from health workers causes problems in the lack of understanding, understanding and compliance of mothers in immunization programs. Based on these data it can be concluded that promotive and preventive efforts have not run optimally.

Globally, an estimated 2-3 million deaths per year have been successfully prevented due to diphtheria, measles, pertussis, polio through immunization, but there are still around 22 million babies in the world who have not received complete immunization and 9.5 million are in the South East Asian region, including Indonesia. This situation is driving global steps in raising awareness of the world community through the implementation of immunizations. Basic health research (2013) states that there was an increase in the number of complete basic immunization coverage from 2007 to 2013. In 2007 the rate of basic immunization coverage was $41.6 \%$ and in 2013 the number of complete basic immunization coverage increased to $59.2 \%$. However, in 2013 there was an incomplete basic immunization coverage of $32.1 \%$ and $8.7 \%$ of children had never been immunized $^{(4)}$.

Complete basic immunization coverage in Surabaya City in the last five years has always been above $85 \%$. In 2018 complete basic immunization in the city of Surabaya was $97.77 \%$. This figure has met the 2018 Strategic Plan target of $93.83 \%$. Meanwhile, according to the Puskesmas, there were 56 Puskesmas (88.89\%) that reached the 2018 Renstra target.

The purpose of this study was to measure the mother's knowledge regarding continuing immunization in the Jagir Public Health Center in 2019.

\section{Method}

This research method uses descriptive approach. Bogdan and Tylor define as a research procedure that produces descriptive data in the form of written or oral words from the people or behavior observed ${ }^{(5)}$.This research was conducted on mothers who are in the working area of Jagir Public Health Center in Surabaya. The subjects in this study were mothers who had 1-2 years old babies in Jagir Urban Village, Surabaya. The subject chosen randomly aside from 3 village. 


\section{Result}

The results of research on maternal knowledge of immunization are described in the following table:

Table 1. Knowledge of Respondents Towards Immunization Services at Jagir Public Health Centerin 2019

\begin{tabular}{|c|l|c|c|c|}
\hline \multirow{2}{*}{ No } & \multirow{2}{*}{ Village } & \multicolumn{2}{|c|}{ Knowing the existence of immunization services at Jagir PublicHealth Center } & \multirow{2}{*}{ Total } \\
\cline { 3 - 5 } & & Yes (\%) & No (\%) & 66 \\
\hline 1 & Jagir & $65(98,5)$ & $2(1,5)$ & 68 \\
\hline 2 & Sawungaling & $66(97,1)$ & $3(4,5)$ & 66 \\
\hline 3 & Darmo & $63(95,5)$ & & \\
\hline
\end{tabular}

The results of table 1 show that the majority of people in the work area of the Jagir Public Health Center in 2019 know about the knowledge of immunization services that is $97 \%$.

Table 2. Results of analysis of families with children under the age of 2019 in the Jagir Public Health Center

\begin{tabular}{|c|l|c|c|c|c|}
\hline \multirow{2}{*}{ No } & \multirow{2}{*}{ Village } & \multicolumn{3}{|c|}{ Families with toddlers } & \multirow{2}{*}{ Total } \\
\cline { 3 - 6 } & & Yes (\%) & No (\%) & No answer (\%) & 66 \\
\hline 1 & Jagir & $52(78,8)$ & $8(12,2)$ & $6(9,0)$ & 68 \\
\hline 2 & Sawungaling & $47(69,1)$ & $16(23,5)$ & $5(7,4)$ & 66 \\
\hline 3 & Darmo & $47(71,2)$ & $16(24,2)$ & $3(4,5)$ & 6 \\
\hline
\end{tabular}

In table 2 it can be seen from the results of the above study that the majority of 3 villages in the work area of the Jagir Public Health Center in 2019 have toddlers, namely 73\%.

Table 3. Results of the analysis of respondents who knew about Continuing immunization services at Jagir Public Health Centerin 2019

\begin{tabular}{|c|l|c|c|c|c|}
\hline \multirow{2}{*}{ No } & \multirow{2}{*}{ Village } & \multicolumn{2}{|c|}{ Who knows about continuing immunization services at Jagir Public Health Center } & \multirow{2}{*}{ Total } \\
\cline { 3 - 6 } & & Yes (\%) & No (\%) & No answer (\%) & $6(13,6)$ \\
\hline 1 & Jagir & $56(84,9)$ & $1(1,5)$ & $15(22,0)$ & 66 \\
\hline 2 & Sawungaling & $53(78,0)$ & $0(0,0)$ & $18(27,3)$ & 68 \\
\hline 3 & Darmo & $46(69,7)$ & $2(3,0)$ & 66 \\
\hline
\end{tabular}

In table 3 it can be seen from the results of the study of the majority of respondents or more than half the number of respondents know that the existence of continuing immunization services at Jagir Public Health Center in 2019 is $77 \%$.

Table 4. Results of analysis of the benefits of continuing immunization according to respondents in the work area of the Jagir Public Health Center in 2019

\begin{tabular}{|c|c|c|c|c|c|}
\hline \multirow[b]{2}{*}{ No } & \multirow[b]{2}{*}{ Village } & \multicolumn{3}{|c|}{ Benefits of Continuing Immunization according to respondents } & \multirow[b]{2}{*}{ Total } \\
\hline & & $\begin{array}{l}\text { Increasing the body's defense and } \\
\text { protection against infections and } \\
\text { various serious diseases }(\%)\end{array}$ & $\begin{array}{l}\text { Make the body strong } \\
\qquad(\%)\end{array}$ & $\begin{array}{l}\text { To enhance the growth } \\
\text { and development of } \\
\text { toddlers }(\%)\end{array}$ & \\
\hline 1 & Jagir & $52(78,8)$ & $3(4,6)$ & $5(7,6)$ & 66 \\
\hline 2 & Sawungaling & $49(72,0)$ & $0(0,0)$ & $4(5,9)$ & 68 \\
\hline 3 & Darmo & $49(74,0)$ & $0(0,0)$ & $2(3,0)$ & 66 \\
\hline
\end{tabular}

In table 4 it can be seen that respondents in the work area of the Jagir Public Health Center in 2019 The majority answered A, namely increasing the body's defense and protection against infections and various serious diseases that is $75 \%$. 
Table 5. Analysis of toddlers who have received further immunizations in the region Jagir Public Health Center work in 2019

\begin{tabular}{|c|l|c|c|c|c|}
\hline \multirow{2}{*}{ No } & \multirow{2}{*}{ Village } & \multicolumn{2}{|c|}{ Toddlers who have received further immunization } & \multirow{2}{*}{ Total } \\
\cline { 3 - 5 } & & Yes (\%) & No (\%) & No answer (\%) & \\
\hline 1 & Jagir & $50(75,8)$ & $7(10,6)$ & $9(13,6)$ & 66 \\
\hline 2 & Sawungaling & $43(63,2)$ & $8(11,8)$ & $17(25,0)$ & 68 \\
\hline 3 & Darmo & $46(69,7)$ & $4(6,1)$ & $16(24,2)$ & 66 \\
\hline
\end{tabular}

In table 5, it can be seen from the results of the respondents above the majority or more than half of the community respondents in the work area of the Jagir Public Health Center in 2019 who have toddlers who have received further immunization at $70 \%$.

\section{Discussion}

According to the Health Act No. 36 of 2009, immunization is an effort to prevent infectious diseases, especially to reduce child mortality. An understanding of immunization is needed by parents as a basis for meeting children's health needs. Provision of basic immunization in children must be based on the existence of a good understanding from parents about immunization as an effort to maintain children's health through disease prevention efforts. So parents are expected to be aware of and have a positive understanding of immunization ${ }^{(6)}$. The results showed that the majority of respondents in 3 villages in the work area of Jagir Public Health Center knew that there was an immunization service at Jagir Public Health Center namely, Jagir village 98.5\%, Sawunggaling village $97.1 \%$ and Darmovillage 95.5\% in this result indicated the respondent's knowledge coverage is good enough.

The quality of immunization services that are less than optimal will certainly waste resources that have been spent such as operational costs, vaccines, immunization logistics, manpower and time. Even what is most concerning for all of us is the failure of immunization will threaten the occurrence of illness, disability or death in children. Basic immunization is very important given to infants aged 0-11 months, in the early days of a baby's life, babies are very susceptible to the disease and if the baby is exposed to the disease it will cause physical, mental, disability and cause death. Immunization is done so that the baby can continue to grow and develop optimally in a healthy state ${ }^{(7)}$. In order to be achieved, immunization coverage must be maintained high and carried out evenly ${ }^{(8)}$.
Furthermore, the results of the study showed that of the 3 urban villages, Darmo Urban Village at least indicated that this village needed more attention or the Public Health Center could be more active in informing that there was an immunization service at Jagir Public Health Center, while the majority in the Jagir Public Health Center work area from 3 villages show that the majority of respondents have toddlers and the percentage of respondents who have toddlers in Darmo is $71.2 \%$.

Immunization is a way to actively raise/increase a person's immunity to a disease, so that if one day he is exposed to the disease it will not be sick or mild illness ${ }^{(8)}$. Infectious disease is the biggest cause of mortality and morbidity in children, so it is very important to do preventive measures through basic immunization. Children have the right to protection from infectious diseases. Children should not receive incomplete immunizations without consideration of consequences for both the child and the community ${ }^{(9)}$.

According to the Indonesian Ministry of Health (2001), the purpose of immunization is to prevent illness and death of infants and children caused by frequent outbreaks ${ }^{(10)}$. The Indonesian government strongly encourages the implementation of the immunization program as a way to reduce morbidity, mortality in infants, toddlers/pre-school children

The results of this study also showed that respondents who knew of continuing immunization services at Jagir Public Health Center in Darmo Village were 69.7\%. Regarding the benefits of immunization, the majority of respondents in Darmo Village answered that the benefits of continued immunization are to increase the body's defense and protection against infections and various serious diseases, which is $74 \%$. And from the results of the study above shows that toddlers in Darmo Village who have received further immunization at $69.7 \%$. 


\section{Conclusion}

Immunization is a way to actively raise/increase a person's immunity to a disease, so that if one day he is exposed to the disease, he will not get sick or mild illness. From the results of the above research it can be said that the majority of respondents in the 3 urban areas of the Jagir Public Health Centre work area know that the Jagir Public Health Centerimmunization service is very good with an average percentage approaching perfect that is $97 \%$.

Based on the above research results it can be concluded that knowledge for basic immunization for infants is very necessary because after all complete basic immunization is very important for toddlers and not only that here also the relationship between the role of parents is needed, especially the mother is very important in providing basic immunization with status baby immunization. Because after all, if minimal parental knowledge of complete basic immunization will affect the health of the toddler.

Conflict of Interest: The authors have no conflict of interest with the material presented in this paper

Sources of Funding: None

Ethical Clearance: None

\section{References}

1. National Development Planning Agency. Pedoman Evaluasi Kinerja Pembangunan Sektoral (Modul 7 Gap Analysis) [Internet]. 2009 [cited 2020 Jun 14]. Available from: www.goodgovermancebappenas. go.id

2. Ministry of Health. Profil Kesehatan Indonesia tahun 2010. Jakarta: Ministry of Health; 2011.

3. Lisnawati L. Generasi sehat melalui imunisasi. Jakarta: Trans Info Media. 2011;

4. Ministry of Health. Riset Kesehatan Dasar 2013. Jakarta: Ministry of Health; 2014.

5. Moleong LJ. Metodologi Penelitian Kualitatif [Research Method for Qualitative]. Bandung, Indonesia: Remaja Rosdakarya. 2010;

6. Surininah. Buku Pintar Mengasuh Batita. Jakarta: PT. Gramedia Pustaka; 2010.

7. Hidayat AAA. Pengantar ilmu keperawatan anak 1.

8. Ministry of Health. Pedoman Penyelenggaraan Imunisasi. Indonesia; 2005.

9. Meadow R, Newwll S. Lecture notes: pediatrika. 2005;

10. Ministy of Health. Pelayanan Informasi Obat. Jakarta: Ministry of Health; 2001. 